DOI: $10.14451 / 2.144 .59$

\title{
К ВОПРОСУ О ЗАЩИТЕ ОКРУЖАЮЩЕЙ СРЕДЫ НА МЕЖДУНАРОДНОМ И НАЦИОНАЛЬНОМ УРОВНЯХ
}

\author{
(c) 2020 Ширёва Ирина Викторовна \\ кандидат юридических наук, \\ доцент Департамента правового регулирования экономической деятельности \\ Финансовый университет при Правительстве Российской Федерации, Россия, Москва \\ E-mail: IVShiryova@fa.ru
}

Сохранение и защита окружающей среды и обеспечение экологической безопасности в настоящее время является одним из наиболее приоритетных вопросов, затрагивающих интересы всех без исключения граждан, проживающих как в нашей стране, так и за рубежом. Количество международных договоров по различным направлениям сотрудничества, которые закрепляют положения об охране окружающей природной среды стало возрастать. В то же время большинство государств приходят к необходимости закрепления права на благоприятную окружающую среду в своих Конституциях. Проводится соответствующая работа как на универсальном, так и на национальном уровнях. В предложенной статьей рассматриваются важные направления этой работы.

Ключевые слова: ЮНЕП, ООН, окружающая среда, Специальный докладчик Совета ООН по правам человека и окружающей среде(Специальный докладчик по вопросу о правозащитных обязательствах, касающихся пользования безопасной, чистой, здоровой и устойчивой окружающей средой), Повестка дня на ХХІ век, Управление Верховного комиссара Организации Объединенных Наций по правам человека (УВКПЧ); Европейский суд по правам человека (ЕСПЧ).

От адвокатов в Мексике до смотрителей парков в Монголии, от преподавателей в Китае, до общинных активистов на острове Мадагаскар, от матери семейства, основавшей экологическую организацию в Кении, до борцов за охрану природы в Швеции и судей в Коста-Рике, от лидеров коренных народов в Бразилии до людей, участвующих в переговорах по климату в Париже, и международных гражданских служащих в Женеве и Найроби - люди по всей Земле стремятся к созданию мира, в котором каждый сможет воспользоваться своими правами человека, зависящими от безопасной, чистой, здоровой и устойчивой окружающей среды [1].

В природе все взаимосвязано и благополучие как отдельного человека, его здоровье, развитие, жизнь, так и жизнь всего человечества зависит от состояния окружающей среды, в которой мы живем. Безопасная, чистая, здоровая и устойчивая окружающая среда является очень важной для реализации широкого круга прав человека, включая права на жизнь, здоровье, питание, водоснабжение и санитарию [2].

Подлежат охране и защите: морская среда; атмосфера (от трансграничного загрязнения воздуха, от истощения озонового слоя, от изменения климата); окружающая среда от ядерных угроз и других опасных видов деятельности; живые ресурсы [3].

Известно, что еще в 1972 году под эгидой ООН была учреждена Программа Организации Объединенных Наций по окружающей среде (ЮНЕП)*. Программа ЮНЕП определяет глобальную экологическую повестку дня, благодаря ЮНЕП происходит информирование государств и их граждан о возможностях улучшить качество

\footnotetext{
* Штаб-квартира находится в Найроби, Кения. Функции и организационная структура Программы ЮНЕП были определены Генеральной Ассамблеей в ее резолюции 2997 (XXVII) от 15 декабря 1972 года. Позднее в 1992 году области деятельности ЮНЕП были расширены в связи с одобрением Ассамблеей Повестки дня на XXI век, и в частности пунктов 21-23 главы 38.[Электронный ресурс] - Режим доступа:// Резолюция 47/190//https://www. un.org/ru/ga/unep/(дата обращения 04.06.2020 г.)
} 
своей жизни без ущерба для качества жизни будущих поколений, ведется работа по поощрению партнерства связанного с заботой об окружающей среде [4].

В принятой Конференцией ООН по окружающей среде и развитию, состоявшейся в Рио-деЖанейро, 3-14 июня 1992 года Повестке дня на XXI век раздел II. посвящен сохранению и рациональному использованию ресурсов в целях развития* .

На универсальном уровне в 1974 году был учрежден Всемирный день окружающей среды, чтобы привлечь внимание к экологическим проблемам. 5 июня 2020 г. по случаю Дня окружающей среды Генеральный секретарь ООН Антониу Гутерриш подчеркнул, что природа посылает нам четкий сигнал: человек наносит ущерб не только окружающей среде, но и себе самому. По словам главы ООН, биоразнообразие исчезает все более быстрыми темпами, а климатические катаклизмы происходят все чаще. «Если нас заботит судьба человечества, мы должны позаботиться о природе»,- заявил он [5].

Продолжая свое выступление, Генеральный секретарь $\mathrm{OOH}$ отметил, что население планеты за последние пятьдесят лет удвоилось, а объем глобальной экономики вырос в четыре раза. Специалисты напоминают, что это привело к нарушению хрупкого равновесия в природе и создало идеальные условия для распространения патогенов, таких как COVID-19. Около миллиона видов растений и животных могут исчезнуть уже в ближайшее время. K такому выводу пришли ученые в результате масштабных трехлетних исследований. Более 90 процентов морских рыбных запасов подвергаются чрезмерному отлову; за последние тридцать лет на Земле было утрачено 28,7 миллионов гектаров лесов. Сегодня страны отменяют карантинные ограничения и приступают к восстановлению экономики. В ООН призывают правительства воспользоваться такой возможностью и вложить средства в «зеленые» проекты: расширять использование возобновляемых источников энергии, строить экологически чистое жилье и транспорт [6].

Следует обратить внимание, что количество международных договоров по различным направлениям сотрудничества, которые закрепляют положения об охране окружающей природной среды стало возрастать. В преамбуле договора о Европейской энергетической хартии 1994 г. отмечена необходимость признания наиболее эффективных способов разведки, производства, преобразования, хранения, транспортировки, распределения и использования

\footnotetext{
* В главах данного раздела предложены соответствующие программные области, цели и действия, необходимые для достижения обозначенных целей по каждому направлению обозначенному в главах, в частности в главе 9 защита атмосферы, главе 10 комплексный подход к планированию и рациональному использованию земельных ресурсов; главе 11 борьба с обезлесением; главе 12 рациональное использование уязвимых экосистем: борьба с опустыниванием и засухой; главе 13 рациональное использование уязвимых экосистем: устойчивое развитие горных районов; главе 14 содействие устойчивому ведению сельского хозяйства и развитию сельских районов; главе 15 сохранение биологического разнообразия; главе 16 экологически безопасное использование биотехнологии; главе 17 защита океанов и всех видов морей, включая замкнутые и полузамкнутые моря, и прибрежных районов и охрана, рациональное использование и освоение их живых ресурсов; главе 18 сохранение качества ресурсов пресной воды и снабжение ею: применение комплексных подходов к освоению водных ресурсов, ведению водного хозяйства и водопользованию; главе 19 экологически безопасное управление использованием токсичных химических веществ, включая предотвращение незаконного международного оборота токсичных и опасных продуктов; главе 20 экологически безопасное удаление опасных отходов, включая предотвращение незаконного международного оборота токсичных и опасных отходов; главе 21 экологически безопасное удаление твердых отходов и вопросы, связанные с очисткой сточных вод; главе 22 безопасное и экологически обоснованное удаление радиоактивных отходов.// Повестка дня на XXI век [Электронный ресурс] - Режим доступа: https://www.un.org/ru/documents/decl_conv/conventions/agenda21.shtml (дата обращения 01.06.2020 г.)
} 
энергии*. Статья 19 посвящена экологическим

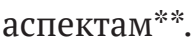

В Повестке дня в области устойчивого развития на период до 2030 года - итоговом докумен- те ООН по устойчивому развитию: Преобразование нашего мира в интересах людей и планеты (25-27 сентября 2015 года)[7] были обозначены 17 целей, среди которых отдельные цели связа-

\footnotetext{
* Указано напоминание о Рамочной конвенции ООН об изменении климата, Конвенции о трансграничном загрязнении воздуха на большие расстояния и протоколах к ней, а также о других международных соглашениях по окружающей среде, касающихся связанных с энергией аспектов; и признание все более срочной необходимости мер по охране окружающей среды, включая выведение из эксплуатации энергетических установок и
} удаление отходов, а также согласованных на международном уровне задач и критериев для этих целей.

** Преследуя цель обеспечить устойчивое развитие и принимая во внимание ее обязательства по международным соглашениям об охране окружающей среды, стороной которых она является, каждая Договаривающаяся Сторона стремится сводить к минимуму экономически эффективными методами вредное Воздействие на Окружающую Среду, имеющее место либо в пределах, либо за пределами ее Территории в результате всех операций в рамках Энергетического Цикла на ее Территории, учитывая надлежащим образом вопросы безопасности. При этом каждая Договаривающаяся Сторона действует, исходя из соображений Экономической Эффективности. В своей политике и действиях каждая Договаривающаяся Сторона стремится принимать меры предосторожности с целью предотвращения или сведения к минимуму деградации окружающей среды. Договаривающиеся Стороны соглашаются с тем, что виновник загрязнения на Территории Договаривающихся Сторон должен, в принципе, нести расходы в связи с загрязнением, включая трансграничное загрязнение, должным образом учитывая общественные интересы и не допуская диспропорций в Инвестициях в Энергетическом Цикле или в международной торговле. Соответственно, Договаривающиеся Стороны: (а) учитывают экологические соображения в ходе всего процесса выработки и осуществления их энергетической политики;

(b) содействуют ориентированному на рынок ценообразованию и более полному отражению экологических затрат и выгод в рамках всего Энергетического Цикла;

(c) учитывая положения Статьи 34(4), поощряют сотрудничество в достижении экологических целей Хартии и сотрудничество в области международных экологических норм в отношении Энергетического Цикла, с учетом различий во вредном воздействии и затратах по ослаблению этого воздействия у Договаривающихся Сторон; (d) уделяют особое внимание Повышению Энергоэффективности, освоению и использованию возобновляемых источников энергии, поощрению применения более чистых видов топлива и использованию технологий и технологических средств, снижающих загрязнение;

(е) содействуют сбору и обмену между Договаривающимися Сторонами информацией об экологически обоснованных и экономически эффективных энергетической политике и Рентабельных методах и технологиях;

(f) содействуют повышению уровня информированности населения о Воздействии на Окружающую Среду энергетических систем, возможностях предотвращения или ослабления их вредного Воздействия на Окружающую Среду и затратах, связанных с различными мерами по предотвращению и ослаблению такого воздействия;

(g) содействуют и сотрудничают в исследованиях, разработках и применении энергоэффективных и экологически обоснованных технологий, методов и процессов, которые позволят свести к минимуму экономически эффективным образом вредное Воздействие на Окружающую Среду всех аспектов Энергетического Цикла;

(h) поощряют создание благоприятных условий для передачи и распространения таких технологий, учитывая необходимость надлежащей и эффективной охраны прав Интеллектуальной Собственности;

(i) способствуют открытой оценке на ранней стадии и до принятия решений, а также последующему мониторингу Воздействия на Окружающую Среду значимых с экологической точки зрения энергетических инвестиционных проектов

(j) способствуют в международном плане повышению уровня информированности и обмену информацией о соответствующих экологических программах и стандартах Договаривающихся Сторон и реализации этих программ и стандартов;

(k) участвуют, по соответствующей просьбе и в рамках имеющихся ресурсов, в разработке и осуществлении соответствующих экологических программ в Договаривающихся Сторонах.

(2) По просьбе одной или более Договаривающихся Сторон, споры, касающиеся применения или толкования положений настоящей Статьи при условии отсутствия в других надлежащих международных форумах положений о рассмотрении таких споров, рассматриваются Конференцией по Хартии с целью их разрешения.// Договор о Европейской энергетической хартии 1994 г. [Электронный ресурс] - Режим доступа: //https://www. energycharter.org/fileadmin/DocumentsMedia/Legal/ECT-ru.pdf(дата обращения 01.06.2020г.) 
ны с окружающей средой и ее сохранением*.

В последние годы признание связей между правами человека и окружающей средой значительно возросло.

В настоящее время многие государства закрепили или предлагают включить в свои Конституции право на здоровую окружающую среду.

Так, статья 42 Конституции РФ гласит, что каждый имеет право на благоприятную окружающую среду, достоверную информацию о ее состоянии и на возмещение ущерба, причиненного его здоровью или имуществу экологическим правонарушением [8].

В 2014 г. в России была разработана государственная программа, касающаяся охраны окружающей среды, принятая постановлением Правительства РФ от 15 апреля 2014 г. N 326 «Об утверждении государственной программы Российской Федерации «Охрана окружающей среды» на 2012-2020 годы [9], ответственным исполнителем указано Министерство природных ресурсов и экологии Российской Федерации. Федеральное агентство научных организаций, Министерство экономического развития Российской Федерации, Федеральное агентство водных ресурсов, Министерство промышленности и торговли Российской Федерации, Федеральная служба по надзору в сфере природопользования, Федеральная служба по гидрометеорологии и мониторингу окружающей среды указаны участниками госпрограммы.

Были обозначены следующие задачи:

- обеспечение качества окружающей среды, необходимого для благоприятной жизни человека;

- сохранение и восстановление биологического разнообразия Российской Федерации;

- повышение эффективности функционирования системы гидрометеорологии и мониторинга окружающей среды;

- организация и обеспечение работ и науч- ных исследований в Антарктике;

- организация и обеспечение работ и научных исследований в Арктике и на архипелаге Шпицберген;

- снижение негативного воздействия на окружающую среду посредством ликвидации объектов накопленного вреда окружающей среде.

В целях реализации задач госпрограммы «Охрана окружающей среды» на 2012-2020 годы были предложены следующие подпрограммы, в том числе федеральные целевые программы:

- регулирование качества окружающей среды;

- биологическое разнообразие России;

- гидрометеорология и мониторинг окружающей среды;

- организация и обеспечение работ и научных исследований в Арктике и Антарктике;

- приоритетный проект «Чистая страна»;

- ликвидация накопленного экологического ущерба;

- обеспечение реализации государственной программы Российской Федерации «Охрана окружающей среды» на 2012-2020 годы;

- охрана озера Байкал и социальноэкономическое развитие Байкальской природной территории на 2012-2020 годы [10].

Во исполнение Указа Президента Российской Федерации от 7 мая 2018 года № 204 «О национальных целях и стратегических задачах развития Российской Федерации на период до 2024 года» Минприроды был разработан паспорт нацпроекта «Экология», который включает в себя 11 федеральных проектов**. Федеральным законом от 26 июля 2019 года № 225-ФЗ внесены изменения в Федеральный закон «Об отходах производства и потребления», которыми предусматривается разработка и утверждение федеральной схемы обращения с твёрдыми коммунальными отходами, устанавливаются

* Так цель номер 3 - обеспечение здорового образа жизни и содействие благополучию для всех в любом возрасте; цель номер 6 -обеспечение наличия и рациональное использование водных ресурсов и санитарии для всех; цель номер 13 - принятие срочных мер по борьбе с изменением климата и его последствиями; цель номер 14 - сохранение и рациональное использование океанов, морей и морских ресурсов в интересах устойчивого развития; цель номер 15 - защита и восстановление экосистем суши и содействие их рациональному использованию, рациональное управление лесами, борьба с опустыниванием, прекращение и обращения вспять процесса деградации земель и прекращение процессов утраты биологического разнообразия.

** «Чистая страна», «Комплексная система обращения с твердыми коммунальными отходами», «Инфраструктура для обращения с отходами I-II классов опасности», «Чистый воздух», «Чистая вода», «Оздоровление Волги», «Сохранение озера Байкал», «Сохранение уникальных водных объектов», «Сохранение биологического разнообразия и развитие экологического туризма», «Сохранение лесов», и «Внедрение наилучших доступных технологий». 
требования [11]. В целях комплексного представления о системе обращения с ТКО федеральная схема будет включать сведения об объектах обработки, утилизации, обезвреживания и размещения ТКО; сведения о планируемых к строительству, реконструкции объектах обработки, утилизации, обезвреживания и размещения ТКО; баланс количественных характеристик образования, обработки, утилизации, обезвреживания и размещения ТКО на территории России; схему потоков ТКО, а также сведения о зонах деятельности региональных операторов по обращению с ТКО.

Распоряжением от 25 декабря 2019 года № 3183-p. был утвержден национальный план [12], который является первым этапом мероприятий по адаптации экономики и населения к изменениям климата и включает в себя институциональные, организационные и методические мероприятия, направленные на формирование государственных подходов к адаптации к изменениям климата.

Подписанным распоряжением предложен национальный план мероприятий первого этапа адаптации к изменениям климата на период до 2022 года, которым определены меры экономического и социального характера, осуществляемые федеральными и региональными органами исполнительной власти в целях уменьшения уязвимости населения России, экономики и природных объектов к последствиям изменений климата, а также использования благоприятных возможностей, обусловленных такими изменениями.

Еще в 2017 году на сайте Минприроды был опубликован проект доклада, касающийся последствий изменения климата и будущих потенциальных опасностей. Так, среди последствий выделены:

- увеличение смертности от экологических катастроф в России;

- температура воздуха в России повышалась более чем в два раза быстрее среднемирового показателя в 0,18 градуса Цельсия за десятилетие;

- концентрация парниковых газов, обусловленная экономическим и демографическим ростом за последние два столетия, в прошлом году достигла рекордных уровней, что привело к беспрецедентным, по крайней мере за последние 800000 лет, уровням атмосферных концентраций углекислого газа (CO2), метана и закиси азота;

- Россия обеспечила себе четвертое место в мире по выбросам парниковых газов после Китая, Соединенных Штатов и Индии;

среди потенциальных опасностей были обозначены:

- Москва и другие крупные города находятся под угрозой более теплой погоды и растущего загрязнения окружающей среды, в то время как пожилые люди в Центральной и Южной России сталкиваются с опасностью тепловых волн. Другие регионы могут стать очагами болезней из-за загрязненной питьевой воды и насекомых;

- Юг России находится под угрозой «новых аварий, связанных с деформацией железных дорог при экстремально высоких температурах»;

- «Перегрев зданий во время тепловых волн вызывает повышенное энергопотребление и способствует возникновению аварийных ситуаций в сфере энерго-и водоснабжения городского населения» в Центральной России;

- Таяние вечной мерзлоты в российской Арктике и вокруг нее может привести к «попаданию опасных химических, биологических и радиоактивных веществ в среду обитания человека»;

- Лесные пожары в Сибири и на других территориях рискуют стать более распространенным явлением, вызывая больше выбросов и угрожая жизни людей. Дальний Восток будет подвержен внезапным наводнениям и муссонам [13].

Очевидно, что в России ведется работа по реализации задач госпрограммы и федеральных целевых программ. Однако, следует отметить, что наше государство сталкивается со сложными проблемами, в частности с проблемой лесных пожаров и загрязнением окружающей среды. Так, летом 2019 г. случился пожар, который, по словам Гринпис России стал самым страшным лесным пожаром в истории. В России было объявлено чрезвычайное положение в Красноярском крае и Иркутской области. Премьерминистр Дмитрий Медведев поручил провести целый комплекс мер по пересмотру того, как страна защищает свои леса. Очевидец Светлана Туфлякова, проживающая в селе Богучаны Красноярского края, примерно в 100 километрах от бушевавших пожаров, охвативших огромные территории и наполнили жилые районы смогом отмечала: «Дышать нечем. Мы не можем от него спрятаться.... Дети и взрослые кашляют без 
остановки.» [14]

Сохранение окружающей природной среды и обеспечение экологической безопасности в настоящее время является одним из наиболее приоритетных вопросов, затрагивающих интересы всех без исключения граждан, проживающих как в нашей стране, так и за рубежом.

Для Российской Федерации эта проблема особенно актуальна. «Только в 2018 году было зафиксировано 12 млрд. рублей ущерба от экологических преступлений»,-цитировал журналистам официальный представитель Генпрокуратуры Игорь Мирошник во время российско-китайского круглого стола в дальневосточном городе Хабаровске. По словам Мирошника, большинство нарушений коснулось лесопромышленного комплекса. За 2018 г. год прокуратура выявила 278 тысяч нарушений природоохранного законодательства и возбудила уголовные дела по 2000 из них, цитирует ТАСС высокопоставленного сотрудника Генпрокуратуры Анатолия Паламарчука [15].

В июне 2020 г. в связи с разливом нефтепродуктов в Норильске Президент России Владимир Путин одобрил введение режима чрезвычайной ситуации федерального уровня. Разлив примерно 20 тыс. тонн дизельного топлива на площади около 350 кв. м произошел из-за разгерметизации одного из резервуаров ТЭЦ НорильскоТаймырской энергетической компании. Нефтепродукты попали в почву, водоем, а также на проезжую часть. Было возбуждено уголовное дело [16].

Очевидно, что многие вопросы, касающиеся взаимосвязи прав человека и окружающей среды требуют дальнейшего изучения.

Необычным аспектом развития правозащитных норм, касающихся окружающей среды, является то, что они не опираются, в первую очередь, на прямое признание права человека на безопасную, чистую, здоровую и устойчивую окружающую среду - или, проще говоря, право человека на здоровую окружающую среду. Хотя это право и было признано в различных формах в региональных соглашениях и в большинстве национальных конституций, оно не нашло отражения в каком-либо глобальном правозащитном соглашении. Договорные органы, региональные суды, специальные докладчики и другие международные правозащитные органы применяли право прав человека при решении экологических вопросов путем добавления «экологической составляющей» в существующие права человека, включая права на жизнь и здоровье.

Важно отметить, что подавляющее большинство стран мира признали это право на национальном, региональном или на обоих этих уровнях. Опыт стран, включивших в своих конституции право на здоровую окружающую среду, демонстрирует реальные преимущества признания этого права. Оно позволило укрепить значимость и важность защиты окружающей среды и заложило основу для принятия более строгих законов об охране окружающей среды. Применение этого права судебными органами способствовало формированию системы защиты от пробелов в статутном праве и созданию возможностей для более полного доступа к правосудию. Суды многих стран все чаще применяют это право, о чем свидетельствует интерес к региональным юридическим рабочим совещаниям, проводимым Программой Организации Объединенных Наций по окружающей среде. В качестве примера могут выступать права на воду и санитарные услуги, которые, как и право на здоровую окружающую среду, не признаются напрямую в правозащитных договорах Организации Объединенных Наций, однако являются безусловно необходимыми для полноценного осуществления прав человека.

В своей резолюции 64/292 от 2010 года Генеральная Ассамблея признала «право на безопасную и чистую питьевую воду и санитарию как право человека, имеющее существенно важное значение для полноценной жизни и полного осуществления всех прав человека». Генеральная Ассамблея могла бы принять аналогичную резолюцию, в которой признавалось бы право на безопасную, чистую, здоровую и устойчивую окружающую среду, так как это право также является основополагающим для полноценной жизни и осуществления всех прав человека. Государства могут по понятным причинам не захотеть признавать «новое» право человека, если его содержание является не до конца определенным, а также важно иметь четкое представление о последствиях его признания.

Даже не будучи формально признанным, термин «право человека на здоровую окружающую среду» уже используется для описания экологических аспектов целого ряда прав человека, которые зависят от безопасной, чистой, здоровой и устойчивой окружающей среды. Ис- 
пользование термина в таком контексте и даже принятие резолюции о признании этого права не меняет правового содержания обязательств, основанных на существующих правозащитных нормах. Тем не менее это имело бы ряд серьезных преимуществ. Например, способствовало бы распространению информации о том, что соблюдение норм в области прав человека требует защиты окружающей среды, и уделению этой защите такого же внимания, как и другим интересам человека, которые имеют основополагающее значение для человеческого достоинства, равенства и свободы. Это также помогло бы обеспечить дальнейшее развитие правозащитных норм, касающихся окружающей среды, на согласованной и комплексной основе. Признание этого права в резолюции Генеральной Ассамблеи способствовало бы дальнейшему укреплению всех этих преимуществ [17].

В 2012 году был учрежден мандат Специального докладчика Совета ООН по правам человека и окружающей среден.

В течение первых двух лет выполнения своего мандата Специальный докладчик стремился более подробно определить круг правозащитных обязательств, касающихся окружающей среды. Он провел ряд региональных консультаций по всему миру и совместно с адвокатами и учеными, предоставлявшими свои услуги на безвозмездной основе, проанализировал сотни заявлений договорных органов, региональных судов по правам человека, мандатариев специальных процедур и других правозащитных органов, обладающих опытом применения норм в области прав человека при решении экологиче- ских вопросов. Результаты этого анализа были приведены в 14 докладах, в каждом из которых он рассматривал сведения, полученные из одного или нескольких источников [18]. Он пришел к выводу, что несмотря на разнообразие источников, высказанные ими мнения относительно взаимосвязи между правом прав человека и окружающей средой в значительной степени совпадают. Эти мнения были резюмированы во втором докладе Независимого докладчика (A/HRC/25/53). Практически каждый из рассмотренных источников указывает на права человека, которые оказываются нарушены или подвергаются опасности в результате нанесения ущерба окружающей среде, и подтверждает, что в соответствии с правом прав человека государства несут обязательства по обеспечению защиты от такого рода ущерба. К ним относятся процедурные обязательства (например, обязанности по предоставлению информации, обеспечению участия и доступа к средствам правовой защиты), материальные обязательства (в частности, по регулированию деятельности частных субъектов) и расширенные обязательства, касающиеся лиц, находящихся в особенно уязвимом положении.

Опираясь на свои исследования и на результаты региональных консультаций, Специальный докладчик также выявил примеры эффективной практики по выполнению этих обязательств и в своем докладе Совету, представленному в марте 2015 года, привел более 100 примеров такой практики (A/HRC/28/61). Кроме того, он опубликовал более подробное описание каждого из этих примеров на веб-сайте Управления Верховного ко-

\footnotetext{
* Он же - Специальный докладчик по вопросу об обязательствах в области прав человека, связанных с пользованием безопасной, чистой, здоровой и устойчивой окружающей средой. В мандате, созданном в марте 2012 года и продленном в 2018 году, рассматриваются обязательства в области прав человека в том, что касается безопасной, чистой, здоровой и устойчивой окружающей среды. Он также пропагандирует передовую практику, связанную с использованием прав человека при разработке экологической политики. Мандат Специального докладчика был утвержден Советом в его резолюции 19/10, в которой он принял решение о назначении независимого эксперта с мандатом на изучение правозащитных обязательств, касающихся пользования безопасной, чистой, здоровой и устойчивой окружающей средой, и на выявление и поощрение передовой практики использования правозащитных обязательств и намерений в отношении информирования, поддержки и укрепления процесса разработки экологической политики. Джон Х. Нокс был назначен на эту должность в августе 2012 года. В своем первом докладе, представленном Совету в марте 2013 года, он подчеркнул, что права человека и охрана окружающей среды неразрывно связаны друг с другом (A/HRC/22/43). Безопасная, чистая, здоровая и устойчивая окружающая среда необходима для полноценного осуществления широкого спектра прав человека, включая права на жизнь, здоровье, питание, воду и развитие. В то же время осуществление прав человека, включая права на информацию, участие и средства правовой защиты, имеет жизненно важное значение для защиты окружающей среды. В настоящее время специальным докладчиком является Д. Боид [Электронный ресурс] - Режим доступа:./ https:/www.ohchr.org/EN/Issues/Environment/SREnvironment/Pages/ SRenvironmentIndex.aspx(дата обращения 03.06.2020 г.)
} 
миссара Организации Объединенных Наций по правам человека (УВКПЧ) и разместил их в виде базы данных с функцией поиска по электронному адресу http://environmentalrightsdatabase. org/. Категории: [19] обязательство содействовать участию общественности в процессе принятия экологических решений (12); обязанность предоставления экологической информации общественности (22); обязательство защищать права на выражение мнений и Ассоциации (8); обязательство обеспечить доступ к средствам правовой защиты (31); обязательства, касающиеся негосударственных субъектов (6); обязательства, касающиеся лиц, находящихся в уязвимом положении (14); обязательства, связанные с трансграничным экологическим ущербом (11); процессуальные Обязательства (7); основные обязательства (9); обязательство предоставлять доступ к средствам правовой защиты [20].

Государства обязаны обеспечивать эффективное средство правовой защиты в случае нарушения охраняемых прав, включая права, осуществление которых нарушается в результате причинения экологического ущерба. Надлежащая практика обеспечения доступа к эффективным средствам правовой защиты в случае причинения экологического ущерба включает: специальные природоохранные суды; процессуальные нормы, облегчающие доступ к судам истцов-экологов; национальные правозащитные учреждения и омбудсмены; а также региональные суды. Так, с точки зрения Специального докладчика имеют значения судебные решения и практика соответствующих судов и работа специализированных органов, а также положения национальных законодательств и проведение исследований, например: решение суда экономического сообщества западноафриканских государств (ЭКОВАС) по проекту «Социальноэкономические права и подотчетность» (Серап) против Нигерии; экологическая компетенция Европейского суда по правам человека; исследование по применению экологического права Финляндии; действия африканской комиссии по правам человека и народов; деятельность Венгерского омбудсмена по делам будущих поколений; решение Мендоса Беатрис Сильва против национального правительства Аргентины; судебная практика Верховного суда Индии, касающаяся охраны окружающей среды, деятельность мексиканской национальной комиссии по правам человека в области охраны окружающей среды, экологическая юрисдикция Конституционного суда Коста-Рики, деятельность Омбудсмена Коста-Рики в области охраны окружающей среды, экологическая судебная практика Верховного Суда Филиппин и др.

Также известно, физические лица для защиты своих прав могут обращаться в Европейский суд по правам человека (ЕСПЧ), базирующийся в Страсбурге с 1998 года.

Хотя в Европейской конвенции нет четкого права на здоровую окружающую среду, суд разработал судебную практику по экологическим вопросам посредством своего толкования гражданских и политических прав в Конвенции. В частности, прецедентное право ЕСПЧ охватывало экологические вопросы в качестве компонентов статей 2 («право на жизнь») и 8 («право на уважение частной и семейной жизни») Конвенции, а также статьи 10 («право на получение и распространение информации») и статьи 1 Протокола № 1. к Конвенции и процессуальные права, такие как право на эффективное средство правовой защиты (статьи 6.1 и 13). Например, в ряде дел, касающихся толкования права на неприкосновенность частной жизни, включая дело Лопес Остра против Испании (1994 год) и дело Ташкин против Турции (2004 год), ЕСПЧ постановил, что государства несут определенные процессуальные обязательства, в том числе они должны следовать процессу принятия решений, который включает «соответствующие расследования и исследования», предоставляет общественности доступ к информации и предоставляет заинтересованным лицам эффективные средства правовой защиты. Суд также установил материально-правовые обязательства государств, как, например, в деле Öneryıldız V. Turkey (2004), установив, что государства несут главную обязанность по созданию законодательной и административной основы, которая защищает от нарушений права на жизнь в результате стихийных бедствий и опасных видов деятельности, включая эксплуатацию химических заводов и мест сбора отходов, и реагирует на них. В таких случаях, как Хаттон В. Соединенное Королевство (2003 год), Европейский суд постановил, что государства имеют право по своему усмотрению устанавливать баланс между охраной окружающей среды и другими общественно важными вопросами, такими как экономическое развитие и права других лиц [21].

В базе данных, разработанной Специальным 
докладчиком, наряду с категориями были выделены следующие промежуточные категории(подкатегории) [22], такие как: доступ к экологической информации (1); доступ к информации, касающейся стихийных бедствий / экологических катастроф (1); ежегодные национальные экологические доклады (4); дети (2); механизмы мониторинга гражданского общества (5); изменение климата (6); конституционное право на здоровую окружающую среду (1); корпоративные действия, связанные с правами человека и охраной окружающей среды (3); судебные решения (4); специальные экологические суды или трибуналы (3); образование и повышение осведомленности (8); природоохранное законодательство с соблюдением строгих процессуальных гарантий (1); руководящие принципы осуществления экологического обзора (1); оценка эффективности участия общественности (1); осуществление руководящих принципов предпринимательской деятельности и прав человека (1); улучшение доступа к суду (5); коренные народы (10); инновационная реализация (1); инновационные механизмы участия (3); международное сотрудничество (3); международные экологические стандарты (1); создание сетей судебных органов и подготовка кадров (1); меньшинства и малообеспеченное население (1); мониторинг и доступ к информации (1); национальные правозащитные учреждения (9); онлайновые инструменты и приложения, связанные с доступом к экологической информации (8); сохранение культурно-исторических мест (1); защита экологических правозащитников (8); участие общественности в разработке природоохранного законодательства (1), участие общественности в оценке воздействия на окружающую среду (1); платформы или органы для участия общественности (5); региональные трибуналы и механизмы (4); оценка трансграничного воздействия на окружающую среду (2); договоры и документы (6); женщины (1).

Необходимо отметить ответственный и конструктивный подход к выполнению своего мандата Специальным докладчиком по правам человека и окружающей среде, Совет по правам человека призвал его продолжать изучать обязательства в области прав человека применительно к пользованию безопасной, чистой, здоровой и устойчивой окружающей средой, а также выявлять и поощрять эффективную практику, относящуюся к этим обязательствам. Были представлены доклады о конкретных аспектах этой взаимосвязи, в том числе доклад об изменении климата и правах человека в 2016 году (А/ HRC/31/52), доклад о биоразнообразии и правах человека в 2017 году (A/HRC/34/49) и доклад о правах детей в контексте окружающей среды для сессии Совета (A/HRC/37/58).

В своей резолюции 28/11 Совет также рекомендовал Специальному докладчику содействовать реализации правозащитных обязательств, касающихся пользования безопасной, чистой, здоровой и устойчивой окружающей средой, сообщать о такой реализации, распространять свои выводы, по-прежнему уделяя особое внимание практическим решениям относительно их осуществления и вести работу по выявлению проблем и препятствий в деле полной реализации этих обязательств. В марте 2016 года Специальный докладчик представил доклад, содержащий конкретные рекомендации относительно правозащитных обязательств, касающихся окружающей среды (A/HRC/31/53).

В целях содействия осуществлению правозащитных обязательств, касающихся пользования безопасной, чистой, здоровой и устойчивой окружающей средой, к Специальному докладчику был обращен настоятельный призыв разработать и распространить четкие и легкие для понимания и применения руководящие принципы, содержащие четкое описание соответствующих норм (см. А/HRC/31/53, пункт 69).

В октябре 2017 года Специальный докладчик опубликовал проект руководящих принципов в области прав человека и окружающей среды:

- Государствам следует обеспечить доступ к безопасной, чистой, здоровой и устойчивой окружающей среде в целях уважения, защиты и осуществления прав человека;

- Государствам следует уважать, защищать и осуществлять права человека в целях обеспечения доступа к безопасной, чистой, здоровой и устойчивой окружающей среде;

- Государствам следует запрещать дискриминацию и обеспечивать равную и эффективную защиту от дискриминации в контексте пользования безопасной, чистой, здоровой и устойчивой окружающей средой;

- Государствам следует принять меры для создания безопасной и стимулирующей обстановки, в которой отдельные лица, группы и органы общества, занимающиеся вопросами прав человека или окружающей среды, могли бы ве- 
сти свою деятельность в условиях отсутствия угроз, притеснения, запугивания и насилия.

- Государствам следует уважать и защищать права на свободу выражения мнений, ассоциации и мирных собраний в связи с экологическими вопросами;

- Государствам следует обеспечивать просвещение и информирование населения по экологическим вопросам.

- Государствам следует обеспечивать доступ общественности к экологической информации путем сбора и распространения данных и предоставления любому лицу легкого, эффективного и своевременного доступа к информации по его просьбе.

- Чтобы избежать принятия мер, экологические последствия которых могут помешать полноценному осуществлению прав человека, или санкционирования таких мер, государствам следует требовать проведения оценки возможных экологических последствий предлагаемых проектов и стратегий, включая их потенциальное воздействие на осуществление прав человека.

- Государствам следует обеспечивать и облегчать участие общественности в процессе принятия решений, касающихся окружающей среды, и принимать во внимание мнение общественности в процессе принятия решений.

- Государствам следует обеспечить доступ лиц, ставших жертвами нарушения прав человека, а также национальных законов, касающихся окружающей среды, к эффективным средствам правовой защиты.

- Государствам следует разработать содержательные экологические стандарты, имеющие недискриминационный и нерегрессивный характер или иным образом способствующие уважению, защите и осуществлению прав человека, и поддерживать их осуществление.

- Государствам следует обеспечить эффективное применение разработанных ими экологических стандартов государственными и частными субъектами.

- Государствам следует сотрудничать друг с другом в целях разработки, применения и обеспечения соблюдения эффективных международных правовых рамок по предотвращению, уменьшению и устранению последствий трансграничного и глобального экологического ущерба, который препятствует полноценному осуществлению прав человека.

- Государствам следует принимать допол- нительные меры для защиты лиц, наиболее уязвимых к экологическому ущербу или подвергающихся в связи с ним особому риску, с учетом их потребностей, рисков и возможностей.

- Государствам следует выполнять свои обязательства по отношению к коренным народам и членам традиционных общин, в том числе посредством:

а) признания и защиты их прав на земли, территории и ресурсы, которыми они традиционно владели и которые они традиционно занимали или иным образом использовали;

b) проведения консультаций с ними и получения их свободного, предварительного и осознанного согласия при принятии решений о переселении их в другое место или при принятии любых других мер, которые затрагивают их земли, территории или ресурсы;

с) уважения и защиты их традиционных знаний и видов практики, касающихся защиты и устойчивого использования их земель, территорий и ресурсов;

d) обеспечения законного и справедливого распределения выгод от деятельности, осуществляемой на их землях и территориях, или при использовании их ресурсов.

- Государствам следует обеспечить уважение, защиту и соблюдение прав человека в своих усилиях по устранению экологических проблем и достижению устойчивого развития.

16 рамочных принципов устанавливают основные обязательства государств в соответствии с правом прав человека в той степени, в какой они касаются пользования безопасной, чистой, здоровой и устойчивой окружающей средой. Каждый из принципов сопровождается комментарием, содержащим более подробное его описание и уточняющим его значение. Рамочные принципы и комментарии к ним не устанавливают новых обязательств. Напротив, они отражают практику применения существующих обязательств в области прав человека в экологическом контексте. Как было отмечено Специальным докладчиком в его аналитическом докладе (A/HRC/25/53), он понимает, что не все государства формально приняли все эти нормы.

Доклад о правах детей в контексте окружающей среды (A/HRC/37/58) был подготовлен Специальным докладчиком в 2018 году [23]. В указанном докладе отмечается, что государства должны делать больше для уважения, защиты и осуществления прав детей в связи с экологи- 
ческим ущербом. В нем излагаются конкретные рекомендации, основанные на работе других специальных докладчиков, Комитета по правам ребенка, УВКПЧ, ЮНИСЕФ, ВОЗ и многих других лиц, представивших устные и письменные сообщения в ходе подготовки доклада.

Что касается образовательных и процессуальных прав детей, то государствам следует, среди прочего:

Обеспечить, чтобы образовательные программы расширяли понимание детьми экологических проблем и укрепляли их способность реагировать на экологические вызовы;

Обеспечить оценку воздействия предлагаемых мер на права детей до их принятия или утверждения;

Собирать информацию об источниках экологического вреда для детей и делать эту информацию общедоступной и доступной;

Содействовать участию детей в процессах принятия экологических решений и защищать их от репрессий за их участие или иное выражение своих мнений по экологическим вопросам.

Государства должны устранить препятствия, с которыми сталкиваются дети на пути доступа к правосудию в связи с экологическим ущербом для полного осуществления своих прав человека.

Государства также несут повышенные обязательства по защите детей от экологического ущерба, в том числе путем обеспечения того, чтобы их наилучшие интересы рассматривались в первую очередь при принятии всех решений, которые могут причинить им экологический ущерб. В частности, государства должны принимать и осуществлять экологические стандарты, соответствующие наилучшим имеющимся научным достижениям и соответствующим международным стандартам в области охраны труда и техники безопасности. Государства никогда не должны принимать регрессивных мер. Они должны принимать меры предосторожности для защиты от экологического ущерба, особенно в тех случаях, когда существует угроза серьезного или необратимого ущерба [24].

Специальный докладчик в сотрудничестве с партнерами приступил к осуществлению последующих мер в связи с докладом о правах детей и окружающей среде, направленных на даль- нейшее поощрение права детей на здоровую и устойчивую окружающую среду [25].

Эта инициатива была начата с учетом Целей устойчивого развития. Задача инициативы состоит в том, чтобы способствовать признанию и осуществлению права детей на здоровую и устойчивую окружающую среду путем:

- расширения прав и возможностей детей и молодежи в отношении их прав на окружающую среду;

- повышения осведомленности и укрепление потенциала национальных, региональных и глобальных директивных органов о взаимосвязи между правами детей и окружающей средой, включая обязательства государств в этой области;

- созыв ключевых заинтересованных сторон и содействие диалогу и более тесному сотрудничеству в связи с осуществлением права детей на здоровую окружающую среду.

Необходимо формирование и обеспечение международного признания глобального свода руководящих принципов, касающихся экологических прав детей, а также информирование об установлении стандартов и разработке политики на глобальном, региональном и национальном уровнях.

В рамках этой инициативы Специальный докладчик организует серию региональных консультаций с целью объединения усилий детей, молодежи и экспертов для обсуждения конкретных экологических проблем, с которыми сталкиваются дети в регионе, и реальных решений этих проблем. В том числе организует цифровые консультации, предоставляет технические рекомендации и инструменты для наращивания потенциала, а также проводит информационнопропагандистскую работу в целях поощрения права детей на безопасную и здоровую окружающую среду на ключевых форумах.

Подводя итоги, следует отметить, что защита окружающей среды остается актуальным и комплексным вопросом, требующим координации усилий как на международном, так и на национальном уровнях с учетом проделанной работы и рекомендаций Специального докладчика Совета ООН по вопросу о правах человека и окружающей среде. 


\section{Библиографический список}

1. Доклад Специального докладчика по вопросу о правозащитных обязательствах, касающихся пользования безопасной, чистой, здоровой и устойчивой окружающей средой от 24 января 2018 г. [Электронный ресурс] - Режим доступа: // UN Doc. A/HRC/37/59 p. 7 (дата обращения 03.06.2020 г.)

2. Официальный сайт Управления Верховного комиссара по правам человека ООН [Электронный ресурс] - Режим доступа: https://www.ohchr.org/EN/Issues/Environment/SREnvironment/Pages/AboutHRandEnvironment. aspx (дата обращения 01.06.2020 г.)

3. C. Redgwell International Environmental Law//International Law. Third Edition. Edited by M. D. Evans. OXFORD University Press.2010. P. 698-717.

4. Официальный сайт программы ЮНЕП https://www.unenvironment.org/about-un-environment/why-does-unenvironment-matter(дата обращения 03.06.2020 г.)

5. Доклад Генерального секретаря ООН по случаю дня окружающей среды 05.06.2020 г. [Электронный ресурс] - Режим доступа: //https://news.un.org/ru/story/2020/06/1379572 (дата обращения 03.06.2020 г.)

6. Доклад Генерального секретаря ООН по случаю дня окружающей среды 05.06.2020 г.[Электронный ресурс] - Режим доступа:// https://news.un.org/ru/story/2020/06/1379572б (дата обращения 03.06.2020 г.)

7. Итоговый документ ООН по устойчивому развитию: Преобразование нашего мира в интересах людей и планеты (25-27 сентября 2015 года) [Электронный ресурс] - Режим доступа: https:/www.un.org/ sustainabledevelopment/ru/wp-content/uploads/sites/5/2015/08/Overview_Sustainable_Development_Summit. pdf (дата обращения 04.06.2020 г.)

8. Конституция РФ // http://www.consultant.ru/cons/cgi/online.cgi?req=doc \&base=LAW \&n=2875 \&fld=134\&dst=1 00163,0\&rnd=0.9557552950953718\#02714746634129619(дата обращения 04.06.2020 г.)

9. Постановление Правительства РФ от 15 апреля 2014 г. N 326 «Об утверждении государственной программы Российской Федерации «Охрана окружающей среды» http://pravo.garant.ru/SESSION/PILOT/main.htm(дата обращения 01.06.2020 г.)

10. Официальный сайт госпрограмм [Электронный ресурс] - Режим доступа https://programs.gov.ru/Portal/ program/12/passport(дата обращения 04.06.2020 г.)

11. Официальный портал Правительства Российской Федерации [Электронный ресурс] - Режим доступа: http:/government.ru/docs/38693/(дата обращения: 01.02.2020 г.) (дата обращения 03.06.2020 г.)

12. Официальный портал Правительства Российской Федерации [Электронный ресурс] - Режим доступа: http://government.ru/docs/38739/(дата обращения: 27.05.2020 г.)

13. Официальный сайт Минприроды [Электронный ресурс] - Режим доступа: https://www.themoscowtimes. com/2018/09/06/russian-ministry-warns-coming-environmental-apocalypse-fueled-climate-changeа62804(дата обращения 27.05.2020)

14. Официальный сайт Voice of America [Электронный ресурс] - Режим доступа: https://www.voanews.com/ europe/siberia-burning-russians-choke-forest-fire-smog(дата обращения 03.06.2020 г.)

15. Официальный сайт The Moscow Times [Электронный ресурс] - Режим доступа: https://www.themoscowtimes. com/2019/06/17/environmental-crimes-cost-russia-186-million-2018-proesutors-a66023

16. Газета Коммерсант от 03.06.2020. Путин объявил ЧС федерального уровня из-за разлива топлива в Норильске//[Электронный ресурс] - Режим доступа: https://www.kommersant.ru/doc/4366010?query=\%D1\%80\%D0 \%B0\%D0\%B7\%D0\%BB\%D0\%B8\%D0\%B2\%20\%D1\%82\%D0\%BE\%D0\%BF\%D0\%BB\%D0\%B8\%D0\%B2\%D0\%B0\%20 \%D0\%B2\%20\%D0\%BD\%D0\%BE\%D1\%80\%D0\%B8\%D0\%BB\%D1\%8C\%D1\%81\%D0\%BA\%D0\%B5(дата обращения 26.05.2020 г.)

17. Доклад Специального докладчика по вопросу о правозащитных обязательствах, касающихся пользования безопасной, чистой, здоровой и устойчивой окружающей средой от 24.01.2018 г. [Электронный ресурс] Режим доступа: https://undocs.org/ru/A/HRC/37/59(дата обращения 01.06.2020 г.)

18. Специальный докладчик по вопросу о правах человека и окружающей среде [Электронный ресурс] - Режим доступа//https:/www.ohchr.org/ru/Issues/Environment/SREnvironment/Pages/SRenvironmentIndex.aspx(дата обращения 01.06.2020 г.)

19. База данных[Электронный ресурс] - Режим доступа http://environmentalrightsdatabase.org/category/(дата обращения 01.06.2020 г.)

20. База данных[Электронный ресурс] - Режим доступа http://environmentalrightsdatabase.org/environmentaljurisprudence-of-the-european-court-of-human-rights/(дата обращения 01.06.2020 г.)

21. База данных[Электронный ресурс] - Режим доступа http://environmentalrightsdatabase.org/environmentaljurisprudence-of-the-european-court-of-human-rights/(дата обращения 03.06.2020 г.) 
22. База данных [Электронный ресурс] - Режим доступа http://environmentalrightsdatabase.org/sub-category/ (дата обращения 03.06.2020 г.)

23. Доклад Специального докладчика о правах детей и окружающей среде (A/HRC/37/58) [Электронный ресурс] - Режим доступа//https://undocs.org/A/HRC/37/58(дата обращения 04.06.2020 г.)

24. Доклад Специального докладчика о правах детей и окружающей среде (A/HRC/37/58) [Электронный ресурс] - Режим доступа//https://undocs.org/A/HRC/37/58(дата обращения 04.06.2020 г.)

25. Специальный докладчик по вопросу о правах человека и окружающей среде [Электронный ресурс] - Peжим доступа https://www.ohchr.org/EN/Issues/Environment/SREnvironment/Pages/environmentandrightschild. aspx(дата обращения 04.06.2020 г.) 